\begin{tabular}{|c|c|c|}
\hline $\begin{array}{l}\text { FATIH } \\
\text { SULTAN } \\
\text { MEHMET } \\
\text { VAKK UNIIVERSIESI } \\
2010\end{array}$ & $\begin{array}{l}\text { FSM İlmî Araştırmalar Insan ve Toplum Bilimleri Dergisi } \\
\text { FSM Scholarly Studies Journal of Humanities and Social Sciences } \\
\text { Sayı/Number } 15 \text { Yıl/Year } 2020 \text { Bahar/Spring } \\
\text { (C2020 Fatih Sultan Mehmet Vakıf Üniversitesi }\end{array}$ & 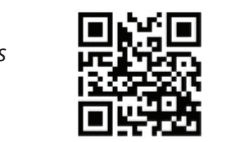 \\
\hline DOI: & http://dergipark.org.tr/fsmia & http://dergi.fsm.edu.tr \\
\hline Araştırma Makalesi / Research Article & Geliş Tarihi / Received: 09.04.2020 Kabul Tarihi / Accepted: 15.05.2020 & FSMIAD, 2020; (15): 159-180 \\
\hline
\end{tabular}

\title{
Edward W. Said'in Oryantalizm Kuramından Hareketle Murat Gülsoy'un Gölgeler ve Hayaller Şehrinde Romanı Üzerine Bir İnceleme
}

Emine Ayan*

\section{Öz}

Batı ile Doğu medeniyeti arasındaki diyaloji ile şekillenen oryantalizm, Batı'nın Doğu'yu alımlama biçimlerine dayanan Batı odaklı epistemolojik bir yaklaşımdır. Yüzyıllar boyunca kurumsal bir bilgi alanı olarak dikkat çeken oryantalizmin, Edward W. Said'in 1978 yılında yayımladığı Şarkiyatçılık Batı'nın Şark Anlayışları adlı kitabı ile kurumsal bir alan olmaktan çıkıp kurgusal bir atmosferde metinler aracılığıyla şekillenen kuramsal bir söylem biçimine dönüştüğü görülür. Michel Foucault'nun bilginin nesnel değil üretilebilir bir olgu olduğu ve iktidarla yakın bir ilişki içinde bulunduğu felsefesinden yola çıkan Said, Batı'nın salt emperyalist edimine odaklı oryantalist yaklaşımını yapı sökümüne uğratır. Said'i kendisinden önceki oryantalistlerden farklı kılan, benimsediği hümanist dünya görüşünün etkisiyle Batı ile Doğu’yu birbiri için gerekli kılarak oryantalizmin tıpkı bir anlatı gibi kurgusal bir düzlemde anlatının bir parçası olarak şekillenen bir söylem olduğunu savunmasıdır.

Bu çalışmada günümüz Türk edebiyatının öne çıkan yazarlarından biri olan Murat Gülsoy'un (1967) Gölgeler ve Hayaller Şehrinde (2014) adlı romanı kuramsal bir analize

* Arş. Gör. Dr., Çukurova Üniversitesi Fen Edebiyat Fakültesi Türk Dili ve Edebiyatı Bölümü, Adana/Türkiye, eayan333@gmail.com, orcid.org/0000-0003-2132-5587 
tabi tutulacak ve oryantalizm bağlamında yazarın postmodern anlatı geleneği içerisindeki konumu belirlenecektir.

Anahtar Kelimeler: Oryantalizm, Edward W. Said, postmodernizm, Murat Gülsoy, Gölgeler ve Hayaller Şehrinde.

\title{
A Research on the Novel Gölgeler ve Hayaller Şehrinde by Murat Gulsoy with Reference to the Orientalism Theory of Edward W. Said
}

\begin{abstract}
Orientalism, shaped by the dialogue between the West and the Eastern civilization, is a Western-oriented epistemological approach based on the forms of the West's uptake of the East. It is seen that orientalism, which has attracted attention as an institutional field of information for centuries, has turned into a form of theoretical discourse formed by texts in a fictional atmosphere rather than being an institutional field with the book of Orientalism Western Conceptions of the Orient of Edward W. Said published in 1978. Said, based on the philosophy of Michel Foucault, that knowledge is not an objective but producible phenomenon and that it has a close relationship with power, deconstructs the orientalist approach of the West, which is focused solely on its imperialist performance. What makes Said different from the previous orientalists is that he defends that orientalism is a discourse formed as a part of the narrative in a fictional plane, just like a narrative, by making the West and the East necessary for each other with the effect of the humanist worldview he adopted.

In this study, the novel called Gölgeler ve Hayaller Şehrinde (2014) of Murat Gülsoy (1967), one of the prominent writers of today's Turkish literature, will be subjected to a theoretical analysis and in the context of orientalism, the position of the author in the postmodern narrative tradition will be determined.
\end{abstract}

Keywords: Orientalism, Edward W. Said, postmodernism, Murat Gülsoy, Gölgeler ve Hayaller Şehrinde. 


\section{Giriş}

Kökeni güneşin doğuşuna karşılık gelen Latince oriens sözcügüne dayanan oryantalizm, en genel anlamda "Doğu bilimi”" anlamını taşır. 18. yüzyılda İngilizcede ve Fransızcada görülen sözcük, 1838'de Dictionnaire de l'Academie française'e "Doğu incelemesi" anlamıla girerek ${ }^{1}$ terminolojik bir açılım kazanır. Oryantalizm Türkçede Şarkiyat, Doğu bilimi; Arapçada istişrak gibi sözcüklerle karşılanır.

Oryantalizmin tarihsel olarak ortaya çıkışı Batı'nın başlangıçta tarım alanında kendisinden daha ileri konumdaki Doğu ile etkileşime geçtiği yıllara ${ }^{2}$ uzanır. VII. yüzyıldan itibaren İslamiyet'in yayılmasıly Doğu'yu bir tehdit olarak alg1lamaya başlayan Batı'nın, İslam özelinde Doğu'ya ilişkin birtakım karşıt imgeler ürettiği görülür. Haçlı seferleri sırasında Doğu ile yakın temasa geçen Batı'da “Öteki”ni daha fazla tanıma yolunda birtakım atılımlar gerçekleştirilir. 12. yüzyılda ilk Kur'an tercümesinin yapılması, 14. yüzyılda dil okullarının açılması ve Arapça, Grekçe, İbranice ve Süryanice kürsülerinin kurulmasının kararlaştı-

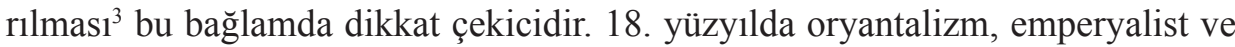
akademik düzlemin kesiştiği bir minvalde ele alınan kurumsal bir bilgi alanı olarak öne çıkar. Doğu'yu 'akademik bir çalışma alanı' kisvesi altında emperyalist amaçlarının bir nesnesi olarak ele alan Batı, Doğu ile ilgili akademik çalışmalarına hız kazandırır. Bu çalışmalar 1001 Gece Masalları'nın Fransızca tercümesi (1704-1717), Kur'an-1 Kerim'in İngilizce tercümesi (1734), 'Doğu despotizmi' kavramı çevresinde geliştirilen düşünceler ${ }^{4}$ gibi örneklerde yansısını bulur. 18 . yüzyılın sonunda Napolyon'un Mısır Seferi (1798) sırasında Mısır'ın işgalini meşru kılan söylemleriyle şekil vererek uyguladığı oryantalist strateji, bu yüzyıla damgasını vurur. 19. yüzyılda oryantalizmin filolojinin yanı sıra sosyoloji, arkeoloji, antropoloji gibi çeşitli disiplinlerde kullanılarak kökleşmiş bir gelenek halini aldığg görülür. Ayrıca bu yüzyılda seyyahların Doğu'ya duyduğu egzotik ilginin izdüşümü olarak fantastik ve düşsel bir Doğu miti oluşur. Bu mitin Fransız edebiyatçıları olan Nerval, Flaubert, Victor Hugo, Chateaubriand gibi sanatçıların kaleme aldıkları eserlerde örnekleri sergilenir.

20. yüzyıl oryantalizm açısından tarihsel bir dönüm noktasıdır. 1973 yılında Paris'teki 29. Uluslararası Oryantalistler Kongresi'nde sömürgecilikle örtüşen

1 Yücel Bulut, “Oryantalizm”, Türkiye Diyanet Vakfi İslâm Ansiklopedisi, cilt 33, İstanbul, Türkiye Diyanet Vakf1 Yayınları, 2007, s. 428.

2 Yüce Bulut, Oryantalizmin Kısa Tarihi, İstanbul, Küre Yayınları, 2014, s. 18.

3 Bulut, a.g.m., s. 429.

4 Bulut, a.g.m., s. 430. 
bir anlamı çağrıştırdığı gerekçesiyle oryantalist teriminin yürürlükten kaldırılma$\mathrm{S1}^{5}$ ve 1978 y1linda Edward W. Said'in Orientalism Western Conceptions of the Orient (Şarkiyatçılık Batı'nın Şark Anlayışları) adlı kitabının yayımlanması bu yüzy1lın dikkat çeken gelişmeleridir. Said de kendisinden önceki oryantalist düşünürlerle benzer olarak Batı ile Doğu medeniyeti arasındaki diyalektiğin şekillendirdiği emperyalist bir kaynaktan beslenmiş; ancak hümanist dünya görüşü ile bu iki medeniyeti birbiri için gerekli kılarak Foucault'nun iktidar-bilgi düalizmine ilişkin kuramsal görüşlerinden hareketle oryantalizmin kurgusal bir atmosferde soluk alan metinsel bir söylem olduğunu savunmuştur. Said'in bu kitabını önceki oryantalist çalışmalardan farklı kılan, oryantalizme ilişkin ansiklopedik bir bilgi aktarmasından ziyade bu bilgi alanını kurgusal bir platforma taşıyarak Doğu'ya has temsil biçimlerine ve bu temsil biçimlerinin Batı iktidarı ile etkileşiminden doğacak olan söyleme odaklanmasıdır.

Oryantalizmi ampirik bir gerçeklikten ziyade mimetik bir gerçeklikle ilişkilendiren Said, bu kavramı "Şark'la . . . uğraşan ortak kurum olarak . . . Şark’a egemen olmakta, Şark'1 yeniden yapılandırmakta, Şark üzerinde yetke kurmakta kullanılan bir Batı biçemi" ${ }^{6}$ olarak tanımlar. Buna göre Batı, somut bir bölge olarak var olan Doğu'yu kendi çıkarları doğrultusunda dönüştürmek suretiyle kimi Doğu temsilleri üretir. Dolayısıyla 'Şarkiyatçının Şark'1, Şark'ın kendisi değil Şarklaştırılmış Şark'tır"’ Batı'nın Şark'a yönelik ediminin temelinde emperyalist zihniyete dayalı ötekileştirme yer alır. Buna göre Batı kendi kimliğini inşa etmek için bir öteki imge olarak dışsallaştırdığı Doğu'yu araçsallaştırır. Said' in Batı'nın Doğu'ya yönelik bu tutumunu düşmanca bir yaklaşımdan ziyade doğal bir sürecin ürünü olarak alımladığı görülür. Ona göre Batı da Doğu da kısmen olumlamalarla kısmen de öteki'nin tespiti yoluyla üretilmiştir ${ }^{8}$

Oryantalizmin bir söylem olduğunu savunan Said'in bu bağlamdaki çııı̧ noktas1 Michel Foucault'nun Bilginin Arkeolojisi (1969) ve Hapishanenin Doğuşu (1975) adlı eserleri olup benimsediği temel felsefe bilginin nesnel değil üretilebilir bir olgu olduğu ve iktidarla yakın bir ilişki içinde bulunduğu görüşüdür. Bilginin oluşumunda nesnel olgulardan ziyade söylemsel bir alanda dönüşüme uğrayıp birbirine eklemlenerek biriken olguların etkili olduğunu belirten Fou-

5 Bulut, a.g.e., s. 1.

6 Edward Wadie Said, Şarkiyatçılık/Batıının Şark Anlayışları, İstanbul, Metis Yayınları, 2013, s. 13 .

7 Said, a.g.e., s. 114.

8 Said, a.g.e., s. ii.

9 Michel Foucault, Bilginin Arkeolojisi, İstanbul, Ayrıntı Yayınları, 2014, s. 212. 
cault'ya göre bilgi bir erk nesnesi olarak iktidar kavramı ile doğrudan ilişkilidir ve "iktidarın ürettiği bir gerçekliğin ürünü"dür. ${ }^{10}$ Foucault'nun söylem analizi bağlamında düşünüldüğünde bilgi Batı'nın çeşitli temsil biçimleri üretmesini olanaklı kılan Doğu malzemesi, iktidar ise bu malzemeyi değiştirip dönüştürerek Doğu üzerinde yetke kurmak için kullanan Batı'dır. Batı ile Doğu arasındaki söz konusu etkileşim de oryantalist söylemi oluşturur. Said'e göre şarkiyatçılık bir söylem olarak incelenmedikçe, Aydınlanma sonrasında Avrupa kültürünün Şark’1 siyasal, sosyolojik, askeri, ideolojik, bilimsel, imgesel olarak üretebilmesini sağlayan sistemli disiplinin anlaşılması olanaksızdır. ${ }^{11}$ Dolayısıyla bilgi ile iktidar oryantalizmin başat iki öğesidir.

Said, şarkiyatçı temsil biçimlerinin Şark hakkında önermeler üretmeye yarayan bir firsatlar dizgesi olduğ $u^{12}$ kanaatindedir. Batı, Doğu'ya ilişkin ürettiği temsil biçimlerini "yaşanan gerçekliği metinlerin hammaddesine dönüştürmek"13 suretiyle kendi çıkarlarına hizmet eden kurgusal bir malzeme olarak kullanır. Metaforik olarak Doğu'yu Doğu'ya has malzemenin sergilendiği bir tiyatro sahnesine; Batı'yı ise bu malzemeden genelleyici/tektipleştirici temsil biçimleri üreten bir izleyiciye benzetmek mümkündür. Oryantalizm kuramı uyarınca Batı'nın Doğu'ya ilişkin ürettiği temsil biçimlerinden Batı kadar, sergilediği çeşitli zaaflarla Doğu da sorumludur. Said'e göre 'Şark, 'Şarklı̆̆ı' keşfedildiği için değil, Şark»ın Şarklı kalınabilmesi -yani Şarklı kılınmışlığa boyun eğmesi yüzünden Şarklaştırılmıştır.”'14

Oryantalizm metinlerarası düzlemde şekillenen bir söylem biçimidir. Buna göre her bir oryantalist metin kendisinden önceki benzer metinlerden izler taşır. Bu yönü ile oryantalizmi temsil biçimleri ile sarmalanmış metinsel bir döngü olarak düşünmek mümkündür. Nitekim oryantalist söylemi oluşturan her bir temsil biçimi hem kendisinden önceki metinlerden beslenir hem de kendisinden sonraki metinlere dayanak teşkil eder. Said'e göre "Şark'la uğraşan her yazar (Homeros bile), gönderme yapacağı, dayanacağı, kendine göre eski bir Şark'1, geçmişteki bir Şark bilgisini temel alır. Ayrıca, her Şark çalışması kendini başka çalışmalarla, izleyicilerle, kurumlarla, Şark' in kendisiyle bağlantılı kılar"15 Said'in metinlerarasılık ile oryantalizm arasında kurduğu ilişkide çıkış noktası söylemi farklı öğe-

10 Michel Foucault, Hapishanenin Doğuşu, Ankara, İmge Yayınları, 2017, s. 286.

11 Said, a.g.e., s. 13.

12 Said, a.g.e., s. 285.

13 Said, a.g.e., s. 95.

14 Said, a.g.e., s. 15.

15 Said, a.g.e., s. 30. 
lerin oluşturduğu bir çoğullukla inşa edilen bir yapı addederek farklı metinlerin nasıl birbirlerine dayandığını gösteren ${ }^{16}$ Foucault'dur.

Said'in kuramsal yaklaşımına göre kurgusal bir düzlemdeki oryantalist söylemden metnin kendi yazarı değil, bizzat metnin kendisi sorumludur. Said'in, Foucault'nun “oluşum kuralları bireylerin 'zihniyetleri'nin ya da bilincinin içinde değil, fakat bizzat, söylemin içinde yerlerini alır . . . bu söylemsel alanda konuşmaya kalkışan bütün bireylere kendilerini empoze eder" ${ }^{\prime 17}$ şeklindeki görüşüne itibar ederek bu yaklaşımı geliştirdiği görülür. Oryantalist söylemde de öne çıkan, metnin tek tek üreticileri değil, söylemin kendisidir. Said'in söz konusu yaklaşımı, benimsediği hümanist dünya görüşünün bir yansısıdır. Çocukluğu iki İngiliz sömürgesinde geçen bir Filistinli olarak doğrudan emperyalist baskıya maruz kalan Said'in, oryantalizmi bireysel bir söylemden ziyade kurgusal bir düzlemde metnin bir parçası olarak şekillenen bir söylem olarak belirlemesi, kendisinden önceki şarkiyatçı tutuma bir eleştiri mahiyeti taşır.

Postmodernizmin hüküm sürdügü bir atmosferde kitabı yayımlanan Said'in oryantalizm ile postmodernizm arasında bir paralellik kurduğu görülür. Avrupamerkezci eğilim ${ }^{18}$ noktasında bu iki alanı ortak bir paydada buluşturan Said, postmodernizmin birer öncel olarak Şarkiyatçılık türünden çalışmaları göz önünde bulundurduğunu ${ }^{19}$ ifade eder. Bu çalışmalar bilgi ile iktidar arasındaki diyalektik, İslam'a yaklaşım biçimi, emperyalist zihniyet, ötekileştirme ve tektipleştirme gibi alanlarda yoğunlaşır. Dolayısıyla postmodern dünyada oryantalist eğilim varlığını büyük ölçüde hissettirir. Bu bağlamda postmodern kurmacaya şekil veren üstkurmaca, metinlerarasılık ve yeni tarihselcilikle ilintili olarak tarihin anlatılaştırılması gibi tekniklerin oryantalist söylemin oluşumunda etkin bir rol oynadığını iddia etmek mümkündür. Postmodern romanlarda herhangi bir yazarın anlatısında karşılaşılan herhangi bir temsil biçimiyle başka bir yazarın anlatısında da karşılaşılması metinlerarasılığın göstergesidir. Said' in "tarih ve onun temsilini sağlayan anlatı . . Şark tarihinin sürekli olarak değiştirilmesine olanak tanır ve tarihin nesnel bir koşulu olmadığını kesinler"20 şeklindeki görüşü, mikro tarihçi bir yaklaşımdan yola çıkıp tarihi anlatılaştıran postmodern tarih algısı ile örtüşür. Anlatı içinde anlatı formuna karşıl1k gelen üstkurmaca da yer yer postmodern anlatıda oryantalist söylemin oluşumunu olanaklı kılan bir teknik olarak dikkat çeker.

16 Michel Foucault, Bilginin Arkeolojisi, s. 143.

17 Foucault, a.g.e., s. 79.

18 Said, a.g.e., s. 365.

19 Said, a.g.e., s. 364.

20 Said, a.g.e., s. 252. 
Türk edebiyatında oryantalizmin tarihçesi Batılılaşma hareketlerinin hız kazandığı Tanzimat yıllarına değin uzanır. Bu dönemde Türk entelijansiyası arasında yaygın olarak dikkat çeken self oryantalist bir eğilim söz konusudur. Batı ile Doğu'nun belirgin bir izlek olarak işlenmeye başladığı bu dönemden 1980'li yıllara kadarki süreçte Türk edebiyatında Doğu kültürüne ötekileştirici bir tutumla yaklaşarak bu kültürü eleştiren oryantalist bir tutum hâkimdir. Postmodernizmin edebiyat dünyasında varlığını hissettirdiği 1980'li yıllardan itibaren ise oryantalizmin postmodern anlatıda bir söylem alanı içerisinde yer bulduğu görülür ve konuya ilişkin çeşitli çalışmalar ${ }^{21}$ dikkat çeker. Bu çalışmada Edward W. Said'in kuramsal yaklaşımı doğrultusunda Murat Gülsoy'un postmodern bir anlatı olarak dikkat çeken Gölgeler ve Hayaller Şehrinde (2014) adlı romanı analiz edilecek ve oryantalizmin söz konusu anlatıdaki görünümünden hareketle yazarın oryantalizme yönelik tutumu açığa çıkartılacaktır.

\section{Edward W. Said'in Oryantalizm Kuramından Hareketle Gölgeler ve Hayaller Şehrinde Romanı Üzerine Bir İnceleme}

Boğaziçi Üniversitesi Biyomedikal Mühendisliği Enstitüsü’nde öğretim üyesi olan Murat Gülsoy, akademisyenliğinin yanı sıra yazınsal faaliyeti bakımından da Türk edebiyatının üretken yazarlarındandır. Gülsoy’un nezdinde

21 Bu bağlamda bkz. Jale Parla, "Efendilik, Şarkiyatçılık, Kölelik", (Yayımlanmamış Doktora Tezi), 1977; Cemil Meriç, "Oryantalizm Boğaziçi Üniversitesi Konferansı”, Sosyoloji Notları ve Konferanslar içinde, 1981, s. 345-349; Ahmet Parlakışı, Oryantalizmin Soruları, 1995; Abdullah Topçuoğlu, Yasin Aktay, Postmodernizm ve İslam, Küreselleşme ve Oryantalizm, 1999; Hilmi Yavuz, Modernleşme, Oryantalizm ve İslam, 1999; Şevket Yıldız, "Oryantalizm ve İslam Tarihine Oryantalist Yaklaşımlar”, (Yayımlanmamış Yüksek Lisans Tezi), Uludăg Üniversitesi, Bursa, 2002; Kasım Küçükalp, "Edward W. Said'in Şarkiyatçılık Düşüncesinin Felsefî Arkaplanı”, Uludă̆ Üniversitesi İlahiyat Fakültesi Dergisi, 12 (1), 2003, s. 269-278; Yücel Bulut, Oryantalizmin Kısa Tarihi, 2004; Yüksel Kanar, Batı'nın Doğu'su/Avrupa Barbarlığının Küreselleşmesi, 2006; Aytaç Yıldız, (Ed.). Oryantalizm: Tartışma Metinleri, 2014; Ali Şükrü Çoruk, "Oryantalizmin Sergüzeşt'i”, İstanbul Üniversitesi Türk Dili ve Edebiyatı Dergisi, 36 (36), 2007, s. 79-100; Onur Bilge Kula, Batı Edebiyatında Oryantalizm-I-II, 2011; Gül Eren, "Edward Said: Oryantalist Söylem Analizinin Metodolojik Temelleri”, (Yayımlanmamış Doktora Tezi), Atatürk Üniversitesi, Erzurum, 2013; Nurullah Çetin, Türk'e Oryantalist Kuşatma, 2014; Servet Erdem, "Osmanlı Türk Romanında Ulusal Oryantalizm ve Oryantalist Uluslaşma”, (Yüksek Lisans Tezi), İhsan Doğramacı Bilkent Üniversitesi, Ankara, 2012; Yadigar Şanlı, “Orhan Pamuk'un romanlarında Doğu-Batı algısı”, (Yayımlanmamış Doktora Tezi), İstanbul Üniversitesi, İstanbul, 2013; Büşra Şahin, “Orhan Pamuk Romanlarında Oryantalizm”, (Yayımlanmamış Yüksek Lisans Tezi), Eskişehir Osmangazi Üniversitesi, Eskişehir, 2015; Emine Ayan, "Edward W. Said' in Oryantalizm Kuramından Hareketle Postmodern Türk Romanlarında Oryantalist Temsiller Üzerine Bir İnceleme”, (Yayımlanmamış Doktora Tezi), Çukurova Üniversitesi, Adana, 2018. 
"devasa bir saray"22 addettiği edebiyat, insanın kendisini, başkalarını ve tüm yaşamını anlaması konusunda en önemli zihinsel çabalarından biridir. ${ }^{23}$ Edebi faaliyetine bir grup arkadaşı ile birlikte 1992 yılında çıkartmaya başladığı $\mathrm{Ha}$ yalet Gemi dergisinde yer verdiği öyküleri ile başlayan yazar, "edebiyata ilişkin kolektif çalışma ortamını önce bir radyo programı, daha sonra da Yaratıcı Yazarlık atölye çalışmaları" ${ }^{24}$ ile sürdürür. Matruşka bebekleri gibi her yazarın içinde çok sayıda başka yazarın saklı olduğunu ${ }^{25}$ düşünen ve bu bağlamda edebi kişiliği Tanpınar-Atay-Pamuk kanalı ile şekillenen Gülsoy, 1999 yılında yayımlanan Oysa Herkes Kendisiyle Meşgul adlı öykü kitabı ile edebiyat dünyasına adim atar. $^{26}$

Murat Gülsoy'un 2014 yılında yayımlanan ve Sedat Simavi Edebiyat Ödülü'ne layık görülen yedinci romanı Gölgeler ve Hayaller Şehrinde, anlatı içindeki anlatı formu ile şekillenen, yer yer okura seslenen ve metinlerarasılığın bir göstergesi olarak kolajlarla, epigraflarla örülen yapısı ile postmodern bir kurmaca niteliği taşır. Roman, tarihi hikâyelere meraklı genç bir avukat olan M.F.A.'nın 1968 yılında sahaflar çarşısından satın aldığı Fransızca el yazmalı defterdeki mektupların tercümesinden oluşur. Söz konusu defter Marsilya'dan İstanbul'a seyahat eden yirmi bir yaşındaki Fuat'ın, Fransa'da tedavi görmekte olan arkadaşı Alex'e yazdığı 1908-1909 tarihli mektupları içerir. Anlatıda Ç.N.'yi (Çevirmenin Notu) ve Y.N.'yi (Yayıncının Notu) içeren dipnotlar deneysel bir teknik olarak dikkat çeker.

II. Meşrutiyet dönemi İstanbul'unun fon teşkil ettiği Gölgeler ve Hayaller Şehrinde, Fransız bir anne ile Türk bir babanın çocuğu olan gazeteci Fuat'ın oryantalist bir amaçla geldiği İstanbul'da geçmişi ile yüzleşmesini konu alır. Ço-

22 Eray Ak, "Edebiyat Devasa Bir Saray Gibidir", Cumhuriyet Kitap Eki, 1447, 2017, s. 20

23 Ayda Baloğlu, "Ve Ateş Bizi Tüketiyor Herkes Kendi Talihinin Mimarıdır”, Paros, 2019, s. 60.

24 Murat Gülsoy, Büyübozumu: Yaratıcı Yazarlık Kurmacanın Bilinen Sirları ve İhlal Edilebilir Kuralları, İstanbul, Can Yayınları, 2019, s. 19.

25 Mehmet Öztunç, "Murat Gülsoy ile Söyleşi”, Türk Dili Dil ve Edebiyat Dergisi, 759, 2015, s. 49.

26 Yazarın sonraki öyküleri Bu Kitabı Çalın (2000), Belki de Gerçekten İstiyorsun (2000), Âlemlerin Sürekliliği ve Diğer Hikâyeler (2002), Binbir Gece Mektupları (2003), Bu An'ı Daha Önce Yaşamıştım (2004), Kâbuslar (2006), Tanrı Beni Görüyor mu? (2010) adlı öykü kitaplarında yayımlanır. Öykülerinin yanı sıra Bu filmin Kötü Adamı Benim (2004), Sevgilinin Geciken Ölümü (2005), İstanbul'da Bir Merhamet Haftası (2007), Karanlı̆̆ın Aynasında (2010), Baba Ŏgul ve Kutsal Roman (2012), Nisyan (2013), Gölgeler ve Hayaller Şehrinde (2014), Yalnızlar Iç̧in Çok Özel Bir Hizmet (2016), Öyle Güzel Bir Yer ki (2017), Ve Ateş Bizi Tüketiyor (2019) adlı romanları bulunan yazar, Büyübozumu: Yaratıcı Yazarlık Kurmacanın Bilinen Strlart ve İhlal Edilebilir Kuralları (2004) ile 602. Gece Kendini Fark Eden Hikâye (2009) olmak üzere iki de inceleme kitabı kaleme alır. 
cukluğu İstanbul'da geçen; ancak dokuz yaşında iken Ermenilerle Türkler arasındaki gerilim yüzünden annesi ve ablası Feride ile İstanbul'u terk edip Marsilya'ya yerleşerek Franck Chausson adını alan Fuat, annesinin ölümü ve ablasının evliliği üzerine para karşılığı İstanbul'a ilişkin yazılar kaleme almak üzere L'llustration adlı bir Fransız gazetesi ile anlaşır. Fotoğrafçı Marcel ile doğduğu şehre yol alan Fuat, bulunduğu gemide Isabella ile tanışır. Annesini metres tutan bir Türk'ün çocuğu olması dolayısıyla kendisinden utanan Fuat'ın buradaki zamanı büyük ölçüde Marcel, Charles ve Evelyn ile İstanbul'un tarihi yerlerine yaptıkları gezilerle geçer. Charles'ın İstanbul hakkında bir kitap hazırlama teklifini kabul eden Fuat'ın, bir yandan şarkiyatçı bir tavır ile Doğu'ya ilişkin hikâyelerin izini sürerken öte yandan da çocukluk kâbuslarıyla boğuştuğu görülür. Doğduğu semt olan Kuzguncuk'a giderek geçmişi ile yüzleşen Fuat, dadısı Halide'den babasının Beşir Fuat olduğunu ve Mehmet Cemil ve Selim adlı iki kardeşi bulunduğunu öğrenir. Mehmet Cemil'in kendisine babasının annesi Marie yüzünden intihar ettiğini söylediği Fuat, kitapçı Arakel'den onun önemli bir kişi olduğunu, uğradığ1 haksızlıkları, annesinin aklını kaçırıp ölmesi üzerine içine düştüğü buhranla kendisini eğlence hayatına verdiği bir sırada tanıştığı annesini hamileliği dolayısıyla Kuzguncuk'a yerleştirdiğini; Ahmet Mithat Efendi'den ise kapıldığı materyalizm felsefesi yüzünden intihar ettiğini öğrenir. Romanda babasındaki "o korkunç delilik tohumu"nun ${ }^{27}$ kendisinde de olması endişesi ile bunalıma sürüklenen Fuat'ın Isabella'yı depremde kaybettiği, Charles, Marcel ve Evelyn ile arasının açıldığ ve Alex’e yazdığı mektupların düzensiz bir hal almaya başladığı görülür. Roman Doğulu ve Batılı kimliği arasında kendisini "zavallı bir gölge . . . bir ifrazat, olmaması gereken önemsiz bir pürüz" ${ }^{28}$ addeden Fuat'ın denize ve yazıya sığınış1 ile son bulur:

"Belki bundan sonraki hayatımda usta bir balıkçı olurum, ne dersin Alex? Niçin olmasın? Boğaz'ın her gün farklı renkte akan sularında, kayığın içinde herkesten ve her şeyden uzak olduğumuzda huzur buluyorum. Nereden aklımda kalmışsa kötü ruhların suyu geçemeyeceğine dair bir inanç beni delirmekten koruyor. Her gece gördügüm kâbuslara bir yenisi ekleniyor ... Sadece denize çıktığımız zamanlarda eski Fuat oluyorum, bir de sana yazarken. Çoktan ölmüş olduğunu aklıma getirmemeye çalışıyorum. Yoksa yazamam. Yazamazsam iyice çıldıracağımı biliyorum"29

27 Murat Gülsoy, Gölgeler ve Hayaller Şehrinde, İstanbul, Can Yayınları, 2014, s. 254.

28 Gülsoy, a.g.e., s. 279

29 Gülsoy, a.g.e., s. 298. 
Gölgeler ve Hayaller Şehrinde oryantalist söylemi ihtiva eden bir anlatıdır. Batı ile Doğu arasındaki diyalektiğin öz kültürüne ötekileştirici bir tutumla yaklaşan self oryantalist figürler ve Batılı figürlerin Doğu dünyası ile etkileşimi arac1lığıyla kurulduğu romanda barbar, despot ve bilimsel olarak geri kalmış bir Doğu temsili üzerinden yansitılan bir oryantalist söylem vardır. Romanda söz konusu figürler aracılığıyla üretilen kimi temsil biçimleri ve İstanbul'da bulunan Batılı figürlerin şarkiyatçı edimlerinden hareketle iktidar ile bilgi mekanizmas1nın devinime geçtiği görülür. Romanın şekillendiği üstkurmaca düzlem, metinlerarasılık ve anlatı olarak işlenen tarih, oryantalist söylemin oluşumunu olanaklı k1lan kurgu teknikleridir.

Gölgeler ve Hayaller Şehrinde romanında Fuat, sergilediği self oryantalist tutum ile Batı'nın çıkarlarına hizmet eden bir şarkiyatçı profili çizer. Fuat'ın İstanbul'la başlayıp gidebildiği kadar Doğu'ya gitmek, dünyayı tanımak, maceralar yaşamak, sonra da bunları kaleme alarak ${ }^{30}$ dünya çapında bir yazar olmak ${ }^{31}$ gayesi ile Batı'dan yola çıkması, Doğu'ya egzotik ilgi duyan şarkiyatçı bir seyyahın tutumu ile örtüşür. İstanbul'da Marcel'la yaptıkları gezintilerde Batılı seyyahlar ne yapıyorsa aynısını yaptıkların1 ${ }^{32}$ dile getiren Fuat'ın self oryantalist tutumunun Charles'ın İstanbul'a ilişkin kitap projesinde de varlığını sürdürdüğü görülür. Bir yandan "Hasta Adam'ın değişen dünyasının kaydını tutma işi”ni" ${ }^{33}$ üstlenen Fuat, öte yandan Doğu'ya Seyahat'ini tekrar tekrar okuduğu Nerval'den ${ }^{34}$ aldığ 1 ilhamla tam bir seyyah gibi hareket ederek İstanbul'a ilişkin hikâyeleri Charles'ın hizmetine sunar. Sergilediği self oryantalist tavırla öz kültürü ile arasına mesafe koyarak kendisini adeta piyonlaştıran Fuat'ın bu tutumu ile Batı'nın Doğu'yu temsil etmesine bizzat olanak tanıdığını iddia etmek mümkündür. Kuramsal bağlamda düşünüldüğünde bu durum Said'in 'Şark, 'Şarklığı' keşfedildiği için değil . . . Şarklı kılınmışlığa boyun eğmesi yüzünden Şarklaştırılmıştır" ${ }^{35}$ şeklindeki savı ile örtüşür. Nitekim romanda Fuat'ın geç de olsa bu gerçekle yüzleştiği görülür. Bu bağlamda onun zihninden akan şu düşünceler, Batı'nın Doğu'ya yönelik oryantalist edimine self oryantalist bir figürün bakış açısından 1şık tutmaktadır:

"Hasta Adam, diyorlar yapmacık bir üzüntüyle ama tedavi etmek için parmaklarını kımıldatmıyorlar. Hastanın ölmesini bekliyorlar. Akbabalar.

\footnotetext{
30 Gülsoy, a.g.e., s. 21.

31 Gülsoy, a.g.e., s. 177.

32 Gülsoy, a.g.e., s. 90.

33 Gülsoy, a.g.e., s. 126.

34 Gülsoy, a.g.e., s. 131.

35 Said, a.g.e., s. 15.
} 
Bunları akıl etmem zaman aldı ama sonunda anladım. Hiçbiri tesadüf değildi. Marcel'la İstanbul'a gitmek üzere görevlendirilmemiz, Charles'ın bize kancayı takması, İstanbul'un esrarlarını ortaya çıkaracağız diye sokak sokak gezmemiz, fotoğraf çekmemiz, hepsi başka bir amaca hizmet ediyor"36

Gölgeler ve Hayaller Şehrinde romanına self oryantalist figürlerce üretilen barbar, despot ve bilimsel olarak geri kalmış bir Doğu temsili hâkimdir. Romanda söz konusu temsil biçimlerinden hareketle Doğu'nun eleştirildiği görülür. Bu bağlamda self oryantalist söylemleriyle öne çıkan Fuat ve Sabahattin Bey'in Doğu'ya ilişkin düşünceleri kuramsal bağlamda romandaki Doğu bilgisine işaret etmektedir.

Gölgeler ve Hayaller Şehrinde romanında çocukluğunda Ermenilerin Osmanlı bankasına düzenledikleri baskının ardından yaşanan Ermeni kıyımına şahit olan Fuat'in, oryantalist için önemli bir temsil oluşturma biçimi olan tektipleştirici bir tutumla genel olarak Türkleri barbarlıkla itham ettiği; hatta babasına duyduğu soğukluğun altında da bu etkenin yattığı görülür. Damarlarında barbar kanı aktığını ${ }^{37}$ duyumsayan Fuat'ın Doğu'nun yüceltildiği bir aforizma olarak dikkat çeken ışık Doğudan yükselir savını Türklerdeki barbarlıkla koşut kıldığı; bu bağlamda da bu 1şığın ya uyuyan güzelin üzerine düştüğünü ya da barbarların kılıçlarında parladığın $1^{38}$ düşündüğü görülür. Barbar bir Türk imgesinin benliğine işlediği Fuat, y1llar sonra geldiği İstanbul'da sözgelimi ibadethanelerdeki sükût ortamını yadırgatıcı bulur:

"İbadethanelerini görsen Alex, o kadar dar sade ve sakin yerler ki. İnsan hakikaten huzur bulabiliyor Bizim Katoliklerin kiliselerindeki o acı, dehşet, korku, gözyaşı burada yok ... Onları bu kadar huzur içinde ibadet ederken görünce insan bütün o barbarlık hikâyelerinin nereden kaynaklandığını anlayamıor. Ama bunları ben şimdi İstanbul'a Paris'ten gelmiş bir yabancı olarak böyle görüyorum. Zamanında annesinin eteğine yapışmış, korkmuş oğlan çocuğunun hafızasında ise elleri baltalı, palalı barbarlar var" ${ }^{\prime 39}$

Taşıdığı Türk kanının onu kadim zamanların barbarlarına bağladığını hisseden Fuat'1n bu histen hem korku hem de biraz gurur duymasi ${ }^{40}$ Türklerin gücünü barbarlığa indirgediğinin göstergesidir. Doğu'daki despotizme dikkat çektiği

36 Gülsoy, a.g.e., s. 269-270.

37 Gülsoy, a.g.e., s. 63.

38 Gülsoy, a.g.e., s. 63.

39 Gülsoy, a.g.e., s. 99-100.

40 Gülsoy, a.g.e., s. 55. 
anlaş1lan Fuat'ın gözünde sultan deyince "ağzında ucundan kan damlayan bir bıçakla kıyımdan dönen Grand Saigner" ${ }^{41}$ addettiği Abdülhamit canlanır. Onun çocukluğu acımasız sultanların hüküm sürdüğü, sadakatsizlik yaptıkları zaman karılarını bir çuvala koyup serin sularına attı̆̆ Boğaziçi denilen masal diyarında geçmiştir. $^{42}$

Romanda Fuat'ın gözünden bilimsel olarak geri kalmış bir Doğu temsiline işaret edildiği görülür. Fuat, depremin günahların kefareti ${ }^{43}$ sayıldı̆̆ 1 , istibdat yanlılarının depremlerde olduğu gibi yangınların da Allah tarafından gönderildiğini ${ }^{44}$ düşündüğü bir Doğu atmosferini soluyarak büyür. Fuat'in çocukluğu dadisı Halide'nin batıl inançlarıyla örülü dünyası ile şekillenir. Babasının bilimle ilgili Doğu'ya ilişkin görüşlerine inanmakta güçlük çeken Fuat'ın Doğu'da bilimsel düşüncenin varlığına ilişkin umudu zayıftır. Bu bağlamda optikten, Camera $\mathrm{Ob}$ scura' dan bahseden Marcel karşısında onun kendisini cahil bir Afrika yerlisi gibi hissetmesi ${ }^{45}$ dikkat çekicidir.

Romanda her üç temsil biçiminin örnekleri babası sürgünde ölen Sabahattin Bey'in Doğu'ya ilişkin düşüncelerinde de görülür. Fuat'1n röportaj yaptığı Sabahattin Bey, "zalim, despot bir hükümdar"46 addettiği sultan Abdülhamit yüzünden II. Meşrutiyetin ilanından sonra Osmanlı'da esen hürriyet rüzgârının uzun süreli olamayacağını savunur. İstibdat döneminde kimseye nefes aldırtmayan, gazeteleri sansürle susturan, hürriyet, anayasa gibi kelimeleri yasaklayan Abdülhamit'in kurduğu tiranlıktan ${ }^{47}$ söz eden Sabahattin Bey, hürriyetin ilanının halk üzerindeki tesirine işaret ederken bu etkinin içerdiği despotizme dikkat çekerek insanların hürriyetin ilan edildiğini duydukları gün korkudan dışarı adım atamadıklarını ${ }^{48}$ ifade eder. İnsanın özelliklerinin asırlar boyunca içinde yaşadığı şartlardan kaynaklandığını; göçebe bir Orta Asya halkı olan Türklerin de maruz kaldıkları sert iklimin etkisiyle reise biati öncelediklerini ve süreç içerisinde İran'ın despotizmini, Bizans'ın entrikalarını aldıklarını ${ }^{49}$ dile getiren Sabahattin Bey'in, Türklerin despotluğunu kökenlerine indirgediği görülür. Doğu'nun barbarlığına ve despotluğuna tepki duyan Sabahattin Bey, ayrıca bu coğrafyanın bilim anlayışını da

41 Gülsoy, a.g.e., s. 53.

42 Gülsoy, a.g.e., s. 25.

43 Gülsoy, a.g.e., s. 72.

44 Gülsoy, a.g.e., s. 128.

45 Gülsoy, a.g.e., s. 57.

46 Gülsoy, a.g.e., s. 44.

47 Gülsoy, a.g.e., s. 56.

48 Gülsoy, a.g.e., s. 55-56.

49 Gülsoy, a.g.e., s. 175. 
eleştirir. Nitekim onun kurmak üzere olduğu rasathane sürgüne gönderildiği için yarıda kalmıştır.

Kuramsal bağlamda irdelendiğinde Gölgeler ve Hayaller Şehrinde romanı Batı'nın Doğu'ya üstün kılındığı bir iktidar mekanizmasının vücuda geldiği bir anlatıdır. Bu bağlamda babasının Beşir Fuat olduğunu öğrenerek geçmişi ile yüzleşen Fuat'ın uğradığı hayal kırıklığından hareketle Doğu'nun Batı karşısındaki geriliğinin yansıtıldığı anlatı, self oryantalist bir figürün öz kültürü ile birebir hesaplaşmasına sahne olur.

Romanda her ne kadar Fuat yer yer Doğu ile Batı arasında arafta kalan bir figür olarak dikkat çekse de ondaki Batılı kimliğin daha ağır bastığını iddia etmek mümkündür. Fuat'ın Batı'da uzun süre saklayarak bastırdığı Doğulu kimliğinden utanç duyarak fikren kendisini bir Fransiz ${ }^{50}$ addetmesi, ötekileştirici bir tavırla İstanbul'a tamamen bir yabanc1 gibi bakmas $1^{51}$ ve kendini Batı'da konumlandırarak "biz" söylemini öncelemesi bu yargıyı destekler niteliktedir. Babasından çok annesine ait olduğunu ${ }^{52}$ düşünen Fuat için İstanbul çocukluğunun uzak masal ülkesi ${ }^{53}$ olup ona "bir barbarın piçi" ${ }^{54}$ olduğunu duyumsatır. Romanda geçmişi ile yüzleşmekten kaçınan Fuat'ın zihninden geçen “yok olup gittiğini, toza, rüzgâra karıştı̆̆ını zannettiğim geçmiş zaman aslında ne kadar da dayanıklıymış. Ben mazi denilen şeyin bu kadar elle tutulur bir hakikat olduğunu asla bilmezdim. Kafam çok karışık . . . . Benden çok uzak olduğuna emin olduğum geçmiş, işte elimi uzatacağım mesafedeydi. Bu şehir, benim Fuat olduğum yerdi" ${ }^{55}$ şeklindeki düşünceler benliğinin altında yatan Doğulu kimliğine duyduğu tepkinin bir ifadesidir.

"Alelade bir adamın metresinden peydahladığ 1 bir zavallı"dan ${ }^{56}$ ziyade savunduğu bilimsel düşünceleri ile devrinde dikkat çeken bir isim olan Beşir Fuat'ın oğlu olduğunu öğrenen Fuat'ın, babasının içinde bulunduğu Doğu atmosferinde maruz kaldığ 1 muameleyle yüzleşmesi kuramsal bağlamda Doğu'nun Bat1 karşısındaki geriliğine işaret eder. Fuat, Voltaire'in girizgâhında İslam'1 yüceltip asırlardır cehalet ve taassup karanlığı içinde bulunduğunu iddia ettiği Hıristiyan

50 Gülsoy, a.g.e., s. 128.

51 Gülsoy, a.g.e., s. 89.

52 Gülsoy, a.g.e., s. 246.

53 Gülsoy, a.g.e., s. 155.

54 Gülsoy, a.g.e., s. 69.

55 Gülsoy, a.g.e., s. 69.

56 Gülsoy, a.g.e., s. 231. 
âlemini yerden yere vurarak ${ }^{57}$ Doğu'nun Batı'dan üstün oluşuna dikkat çeken; Victor Hugo biyografisinde ise Hugo'ya Emile Zola'nın gözlügüule bakarak natüralizmin savunuculuğunu yapan ${ }^{58}$ babasının ömrünü bilime adayan bir Türk düşünürü olduğunu anlar. Hayale karşı hakikati, şairlerin romantik rüyalarına karşı bilimin akıcılığını savunan ${ }^{59}$ Beşir Fuat'ın fikirlerine döneminde karşı ç1kılması Doğu'nun bilimsel olarak geri kalmışlığına; dolayısıyla da romandaki temsil biçimine dayanak teşkil eder. Romanda Fuat'in Ahmet Mithat Efendi'nin babasına ilişkin kaleme aldığı kitabı ile Doğu'daki taassuba tanık olduğu görülür. Kitabında Beşir Fuat ile nasıl tanıştığına, onun sefahat düşkünlüğüne ve intihar şekline ${ }^{60}$ yer veren Ahmet Mithat, Fuat'a babasının materyalizm denilen felsefeye kapıldığ 1 için intihar ettiğini ${ }^{61}$ söyler. Yüzleştiği gerçekler karşısında kendisini "gökyüzünde uçan kimsesiz bir tohum" ${ }^{22}$ gibi hisseden Fuat'1n aklî dengesini yavaş yavaş yitirmeye başlayarak içine kapanması babasıyla aynı kaderi paylaştı̆̆ının göstergesidir. Babasıyla gurur duyan; ancak fikirleri yüzünden maruz kaldığı muamele karşısında Doğu'ya ilişkin tüm umudunu yitiren Fuat, babasını Doğu taassubunun öldürdüğünü düşünür. Bu bağlamda Fuat'ın şu cümleleri Beşir Fuat'ın Doğu'yu Batı'ya üstün kılan tezini çürüten Doğu zihniyetini yansıtarak Doğu'nun Batı karşısındaki mağlubiyetine işaret eder:

"Babam bu topraklarda doğmuş en akıllı adamdı . . . bundan kesinlikle eminim. Ama fikirleri bu memleket için zamanının çok ilerisindeydi. Fransa ya da İngiltere'de yaşayan, benim diyen yazarlardan, şairlerden bile ileriydi. Elbette yaşatmayacaklard. Öldürdüler onu . . . İntihar etmedi, öldürdüler. Bu ilk cinayetleri değil . . . . Babamın zayıf anından yararlanıp onun aklına girdiler ... Babamı yok etmek için onu deli olduğuna inandırdılar. Sultan Murat'a yaptıkları gibi. Başına sülükler bağladılar. Kanını emdiler. Kanı azaldıkça zihni bulandı, sisler içinde bir gemiye dönüştü. Onu yok ettiler. Çünkü o Voltaire gibiydi . . . . İnsanlar ne kadar boş inançların içinde ömürlerini heba ettiklerini anlayacaklardı onun sayesinde. Sinsice planladılar ölümünü’’3

57 Gülsoy, a.g.e., s. 232-233.

58 Gülsoy, a.g.e., s. 234.

59 Gülsoy, a.g.e., s. 237.

60 Gülsoy, a.g.e., s. 246.

61 Gülsoy, a.g.e., s. 270.

62 Gülsoy, a.g.e., s. 291.

63 Gülsoy, a.g.e., s. 274-275. 
Batı'yı yeni; Doğu'yu ise eski dünya ${ }^{64}$ addeden Fuat, yüzleştiği gerçekler karşısında Batı'yı Doğu'ya üstün kılan bir söylemle Amerika'ya değil de İstanbul'a gittiği için pişmanlık duyar. Romanda söz konusu söylemin İstanbul'daki sözde hürriyet atmosferinden hareketle de yansıtıldığı görülür. Babasının maruz kaldığg muameleyi göz önüne alarak Doğu'da hürriyet fikrinin adeta parodisini yapan Fuat, hürriyet coşkusunun hüküm sürdüğü Doğu atmosferinde bu fikrin kofluğuna işaret eder. Ona göre eşitlik, kardeşlik, laflarından geçilmeyen ${ }^{65}$ İstanbul'da hürriyet "kimsenin uyanmak istemediği bir rüya"dır. ${ }^{66}$ Fuat bunun sebebini de Doğu'nun taassuplarla örülü zihniyetine bağlamaktadır.

Gölgeler ve Hayaller Şehrinde romanında iktidar ile bilgi arasındaki diyalektiği vücuda getiren bir diğer olgu, İstanbul'da bulunan Batılı figürlerin şarkiyatçı edimleridir. Fuat ve Sabahattin Bey gibi self oryantalist figürlerce örnekleri sergilenen temsil biçimlerinin Batılı figürler aracılığıyla da yer yer sergilendiği romanda söz konusu figürlerden hareketle Doğu üzerinde hâkimiyet kurmak isteyen Batı zihniyetinin bilgiyi işlemek suretiyle bu emeline nasıl ulaştığı yansitılır.

Romanda Fuat'1n Marsilya'dan İstanbul'a seyahat ettiği gemide karşılaştığ Pierre de Bouise'un Osmanlı'daki yönetim sistemine ilişkin çizdiği despot Doğu temsili ile Batı'nın hoşuna gidecek bir Doğu imgesi yarattığı görülür. Osmanlı imparatorluğunun hiç parçalanmadan o günlere gelişini evlenmeyip haremindeki kölelerinden çocuk sahibi olan sultanın bu suretle başka bir hanedanla iktidarını paylaşmak zorunda kalmayışına ${ }^{67}$ bağlayan seyyah, Osmanlı' daki kölelik sistemine işaret ederek Abdülhamit'i "Doğulu bir despot" ${ }^{68}$ addeder. Gemideki İtalyanlardan biri ise Türkleri korkunç gösteren Mamma li Turchi deyişiyle ${ }^{69}$ Fuat'la dalga geçer. Romanda Marcel'ın Fuat'la yaptıkları Ayasofya gezisinde anlattığ 1 Türklerin barbarlığını içeren hikâye de bu bağlamda dikkat çekicidir:

“İşgal sırasında Ayasofya'nın rahibi mihrabın önünde dua ediyormuş. Türklerin kiliseye girdiklerini görünce ayini yarım bırakmış, kutsal vazoları alıp kaçmış. Barbarlar peşinden koşmuşlar ama rahip son derece sakin bir şekilde duvarın içinden geçip kaybolmuş. Burada gizli bir geçit olduğunu sanıp günlerce duvarı delmeye çalışmışlar ama boşuna. Duvarda hiçbir

\footnotetext{
64 Gülsoy, a.g.e., s. 68.

65 Gülsoy, a.g.e., s. 68.

66 Gülsoy, a.g.e., s. 290.

67 Gülsoy, a.g.e., s. 24.

68 Gülsoy, a.g.e., s. 24.

69 Gülsoy, a.g.e., s. 61.
} 
hile yokmuş . . . Marcel rahibin halen yaşadığına ve burası tekrar Hıristiyanların eline geçince duvarın içinden çıkıp ayine kaldığı yerden devam edeceğine inanıldığını söyledi’’70

İstanbul'daki şarkiyatçı figürlerden hareketle Doğu'ya yönelik egzotik ilginin sergilendiği romanda, Doğu üzerinde yetke kurma çabası içinde olan bu figürlerin uyguladıkları şarkiyatçı stratejiler, bilgiyi bir erk nesnesi olarak alımlayan Batı zihniyetine 1şık tutar. Bindiği gemide yoğun bir oryantalist atmosferle karşılaşan Fuat, İstanbul'da bu atmosferin adeta bir parçası haline gelir. Romanda Fuat'ın "insan ayağı değmemiş okyanus adalarında keşif yapan bir alim"e e $^{71}$ benzettiği Marcel'ın oryantalist bir strateji ile kendisinden önce İstanbul'a gelen seyyahların yazdıklarının izini sürdüğ̈̈; aradığını bulduğunda ise oyuncağına kavuşmuş bir çocuk gibi sevindiğ $i^{72}$ görülür. Onun bilhassa Müslüman mahallelerine ve hareme merak duyması şarkiyatçı bir figürün tutumu ile örtüşür. Nitekim tekke ve harem metaforik olarak Doğu'yu oryantalist malzemenin sergilendiği bir tiyatro sahnesine benzeten şarkiyatçı zihniyetin iki kilit mekânıdır. Romanda bu iki mekâna ilişkin çizilen tablolara yer verilmesi, Doğu'ya ilişkin bilgiyi değiştirip dönüştürerek kendi çıkarlarına uygun Doğu imgeleri üreten egzotik Doğu mitine birer örnek teşkil eder. Sözgelimi romanda şarkiyatçı bir figür olan Charles, hayalindeki haremi "sadece insanın Doğu' ya dair hayallerini okşayan uydurma kitaplarda var olan bir rüya" "73 olarak tanımlar. Charles'ın İstanbul'u "şehirlerin kraliçesi" " addederek bu şehre ilişkin hazırladığı kitap için para karşılığ Fuat'ın bilgisinden yararlanması ve İstanbul'un esrarlı hikâyelerinin peşine düşerek derlediği efsane kırıntılarından anlaşılır hikâyeler uydurmas1 $^{75}$ şarkiyatçı zihniyetle birebir örtüşür. Romanda yüzleştiği gerçekler karşısında hayal kırıklığına uğrayan Fuat'ın aksine Marcel ve Charles'ın Batı'nın çıkarları doğrultusunda hazırladıkları İstanbul kitabını tamamlayarak bir başka Doğu seyahatine çıktıkları görülür. Bu durum kuramsal bağlamda Batı'nın Doğu karşısındaki galibiyetine işaret etmektedir.

Gölgeler ve Hayaller Şehrinde romanında anlatının şekillendiği üstkurmaca düzlem oryantalist söylemin oluşumunu olanaklı kılması ile dikkat çeker. Bu bağlamda romanın üstkurmaca zeminini oluşturan mektupları başlı başına oryan-

70 Gülsoy, a.g.e., s. 91.

71 Gülsoy, a.g.e.,. 91.

72 Gülsoy, a.g.e., s. 94.

73 Gülsoy, a.g.e., s. 211.

74 Gülsoy, a.g.e., s. 117.

75 Gülsoy, a.g.e., s. 228. 
talist bir vesika olarak nitelendirmek mümkündür. Romanda Fuat Alex'e yazdığı mektuplarda Doğu'ya ilişkin adeta oryantalist bir tablo çizmekte ve bu tabloyu kimi mektuplarının sonuna iliştirdiği kartpostallar ile tamamlamaktadır. Fuat'ın "acayip bir şehir" görülür. Ayrıca romanda Charles'ın İstanbul'a ilişkin hazırladığı kitabın adının "Gölgeler ve Hayaller Şehrinde" olduğuna ilişkin anıştırmalar yer alır. Fuat'ın aldığ 1 afyonun tesiri altında iken gördüğü bir rüyada söz konusu kitabı Mösyö Girard'a teslim ettiğini ${ }^{77}$ görmesi ve romanın sonunda İstanbul'u "gölgeler ve hayaller şehri" ${ }^{\prime 78}$ addetmesi bu bağlamda dikkat çekmektedir.

Metinlerarası atmosferin yoğun olarak varlığını hissettirdiği romanda bu atmosfer aracılığıyla vücut bulan bir oryantalist söylem söz konusudur. Nerval, Gautier, Edmondo de Amicis gibi seyyahların kitaplarına, Ahmet Mithat Efendi'nin Beşir Fuat'ına, Beşir Fuat'ın Voltaire ile Victor Hugo biyografilerine gönderme yapılan romanda, metinlerarası dokunun oryantalist söylemi işaret eden bir öze sahip olduğu görülür.

Postmodern bir atmosferde tarihin bir dekor olarak kullanıldığ Gölgeler ve Hayaller Şehrinde romanı, İkinci Meşrutiyet dönemi İstanbul'unun oryantalist bir minvalde işlendiği bir anlatıdır. Romanda tarihin ele alınış biçimi itibariyle oryantalist söylemin oluşumunda etkin bir rol oynadığı görülür. Ahmet Cevdet Bey, Beşir Fuat, Ahmet Mithat Efendi, II. Abdülhamit gibi tarihi kişiliklerin anlatı düzlemine taşındığ 1 , mikro tarihçi bir yaklaşımla İstanbul'un gündelik yaşamına ilişkin örüntülerin dikkat çektiği romanda, oryantalist bir zeminde Doğu'ya ilişkin olumsuz bir tarih imajının çizildiği görülür. Dilencileri, hastalıklı çocukları, hamalları, ${ }^{79}$ sur diplerine yaslanmış acayip evlerde yaşayan fakir insanları, ölümü bekleyen yaşlıları, başıboş hayvanları, hangi zamanda yaşadığını bilmeyen yarı çıplak çocukları ${ }^{80}$ ile pitoresk bir İstanbul imajının çizildiği romanda, oryantalist bir veri olarak dikkat çeken bir tarih motifi söz konusudur. Bu bağlamda romanda Charles'ın hazırladığı kitap için tarihi hikâyeleri derlemesi dikkat çekicidir. Sözgelimi bu hikâyelerden birinde Sultan Murat'in barbar bir padişah ${ }^{81}$ olarak resmedilip romandaki barbar Doğu temsiline işaret edildiği görülür. Söz konusu Doğu temsilinin örneğine Marcel'ın Ayasofya'ya ilişkin anlattığı bir hikâyede

\footnotetext{
76 Gülsoy, a.g.e., s. 112.

77 Gülsoy, a.g.e., s. 196.

78 Gülsoy, a.g.e., s. 299.

79 Gülsoy, a.g.e., s. 78.

80 Gülsoy, a.g.e., s. 123.

81 Gülsoy, a.g.e., s. 159.
} 
Fatih Sultan Mehmet'in barbarlığına ${ }^{82}$ dikkat çektiği bir hikâyede de rastlanır. Romanda Fuat-Marcel-Charles üçlüsünün adeta oryantalist bir tarih işçiliğini üstlendiğini iddia etmek mümkündür.

Gölgeler ve Hayaller Şehrinde romanı Murat Gülsoy'un materyalizmi bir felsefe olarak benimsemeye çalışan bir çocukken okuduğu bir ansiklopedide rastladığ 1 Beşir Fuat' $1 n^{83}$ intihar ile sonuçlanan yaşam hikâyesinden esinlenerek kaleme aldığı romanıdır. Gülsoy’un, romanında beslendiği iki kaynak Ahmet Mithat Efendi'nin ve Orhan Okay'ın Beşir Fuat'a ilişkin eserleridir. Yazarın bu romanı kaleme almaktaki amac1 "hikmet-i batıla" ${ }^{44}$ addettiği materyalizm felsefesine şiddetle karşı çıkan Ahmet Mithat Efendi’nin Beşir Fuat'a ilişkin çizdiği olumsuz imajı kırarak onun Doğu dünyasına bilimsel olarak sunduğu katkıya kurmaca bir dünyada 1şık tutmaktır. Nitekim karısından iki oğlu, metresinden de bir kızı olmak üzere sağ olarak üç çocuğu bulunan ${ }^{85}$ Beşir Fuat'in Fuat isimli bir oğlu yoktur. Yarattığı kurmaca atmosferde s1klıkla gönderme yaptığ 1 Ahmet Mithat Efendi'nin kitabında sözünü ettiklerine büyük ölçüde bağlı kaldığı anlaşılan Gülsoy, Tanzimat devri Türk edebiyatında bir dönem etkisini hissettiren hayaliyyun-hakikiyyun polemiğine de temas eder. Beşir Fuat'ın Victor Hugo biyografisi hakkında Menemenlizade Tahir'in yaptığ 1 tenkitle başlayan bu polemik, bir edebiyat-fen, romantizm-realizm, şiir-hakikat münazarası şekline dönüşür. ${ }^{86}$ Şiirde de romanda olduğu gibi rasyonel bir gerçeklik arayan ${ }^{87}$ Beşir Fuat, aralarında Ahmet Mithat Efendi'nin de yer aldığı devrin pek çok ismiyle ters düşer. Beşir Fuat'ın vatanına, milletine hizmet eden bir yazar olduğunu ${ }^{88}$ kabul etmekle birlikte dini bilgisinin zayıflığ $1^{89}$ yüzünden kapıldığını düşündüğü materyalizm felsefesi dolayısıyla ona tepki duyan Ahmet Mithat Efendi, bu tepkisini "Materyalizmin Reddiyle İntihar Hakkında Muhakeme" ${ }^{90}$ başl1klı reddiyesinde dile getirir. Ahmet Mithat Efendi ahireti dikkate almayan ${ }^{91}$ materyalistlerin tıpkı Beşir Fuat gibi kendi kendilerini

82 Gülsoy, a.g.e., s. 93.

83 Sibel Oral, "Murat Gülsoy'dan Gölgeler ve Hayaller Şehrinde”, Cumhuriyet Kitap, 1261, 2014, s. 22.

84 Ahmet Mithat Efendi, Beşir Fuat, İstanbul, Dergâh Yayınları, 2017, s. 78.

85 Orhan Okay, Beşir Fuad İlk Türk Pozitivist ve Natüralisti, İstanbul, Hareket Yayınları, 1969, s. 46.

86 Okay, a.g.e., s. 55.

87 Okay, a.g.e., s. 162.

88 Ahmet Mithat Efendi, a.g.e., s. 20.

89 Ahmet Mithat Efendi, a.g.e., s. 29.

90 Ahmet Mithat Efendi, a.g.e., s. 69.

91 Ahmet Mithat Efendi, a.g.e., s. 73. 
idama mahkûm ettikleri ${ }^{92}$ kanısını taşır. Metinlerarası bir atmosferde Ahmet Mithat Efendi'nin bu türden görüşlerine romanında sıkça yer veren Gülsoy, kendisiyle yapılan bir söyleşide ifade ettiği üzere onun muhafazakârlı̆̆ına tepki duyan ${ }^{93}$ bir yazardır.

Ahmet Mithat Efendi'nin 1980'lerde yeniden gündeme gelmesini onun hayata ve meselelere bakış şeklinin bu yıllarda da mevcut bir söylem olarak dikkat çekmesine bağlayan Gülsoy'un, bu söylemi Batı ile Doğu çatışması ile ilişkilendirdiğ $i^{94}$ görülür. II. Meşrutiyet dönemi İstanbul'unda "genel olarak Müslüman değerlerden uzaklaşarak Batılı seküler bilimsel bir bakış açısı benimsemenin varacağ1 'korkunç' sonuç"a ${ }^{95}$ dikkat çektiği anlaşılan yazar, Ahmet Mithat Efendi'den hareketle Tanzimat dönemindeki Batılılaşma izleğinin Türk aydını üzerindeki etkisine işaret ederek bu özelde Beşir Fuat'1 "ezilmek ve yok edilmek istenen aydın arketipi" ${ }^{\prime 96}$ addeder. Oryantalizme yönelik yoğun bir araştırma sürecinin ürünü olduğu anlaşılan romanda yazarın oryantalist bir söylemle kurmaca bir dünya inşa ettiğini söylemek mümkündür. Batı ile Doğu medeniyeti arasındaki çatışmayı benliğinde duyumsayan biri olarak, yaşadığ 1 şehrin geçmişini görme isteği ${ }^{97}$ ile yola çıkan Gülsoy'un Beşir Fuat için yola çıkmışken kendisini Beşir Fuat'1 değil onun izini süren Fuat'ın zihninin içinde bulduğunu ${ }^{98}$ dile getirmesi bu yargıyı desteklemektedir. "Batı sadece Batı'da değildir. Batı da Doğu da her yerdedir" kurguladığı Fuat aracılı̆̆g ile Doğu dünyasında hüküm süren oryantalist zihniyeti ortaya koyar.

\section{Sonuç}

Murat Gülsoy'un Gölgeler ve Hayaller Şehrinde romanının oryantalizm kuramı bağlamında bir analize tabi tutulduğu bu çalışmada, romanın oryantalist söylemin kuramsal altyapısını ihtiva eden bir anlatı olduğu anlaşılmıştır. İstanbul'un mekân olarak seçildiği bir atmosferde barbar, despot ve bilimsel olarak geri kalmış Doğu temsillerinin sergilendiği romanın Fuat özelinde self oryantalist zihniyetin Doğu ve Batı ile olan hesaplaşmasını ihtiva ettiği sap-

92 Ahmet Mithat Efendi, a.g.e., s. 74.

93 Handan İnci, "Bugünün Gözüyle Ahmet Mithat”, Kitap-lık, 165, 2013, s. 111.

94 İnci, a.g.m., s. 117.

95 Oral, a.g.m., s. 22.

96 Oral, a.g.m., s. 22-23.

97 Öztunç, a.g.m., s. 39.

98 Öztunç, a.g.m., s. 40.

99 Oral, a.g.m., s. 22. 
tanmıştır. Tanzimat döneminde hüküm süren Batılılaşma hareketinin Türk entelijansiyası üzerindeki etkisine kurmaca bir dünyada tarihi bir kişilik olarak kurguladığı Beşir Fuat'ın biyografisinden hareketle dikkat çeken Gülsoy'un Doğu- Batı izleğinin odağa alındığı oryantalist bir düzlemde bu döneme $1 s ̧ 1 k$ tuttuğu görülmüştür.

Çalışmada Gülsoy tarafından oryantalist bir söylem kanalıyla gerçekleştirilen bir Doğu eleştirisinin yapıldığı sonucuna ulaşılmıştır. Oryantalizmin kuramsal çerçevesine vakıf bir yazar olduğu anlaşılan Gülsoy, bu söylemi anlatısının bir parçası kılarak yansıtması ile öznenin değil söylemin odağa alındığı postmodern anlatı geleneği içerisindeki oryantalist zincire eklemlenen bir yazardır. 


\section{Kaynakça}

Ahmet Mithat Efendi, Beşir Fuat, yay. haz. B. Dervişcemaloğlu, İstanbul, Dergâh Yayınları, 2017.

Ak, Eray, "Edebiyat Devasa Bir Saray Gibidir", Cumhuriyet Kitap Eki, 1447, 2017.

Ayan, Emine, "Edward W. Said'in Oryantalizm Kuramından Hareketle Postmodern Türk Romanlarında Oryantalist Temsiller Üzerine Bir İnceleme", (Yayımlanmamış Doktora Tezi), Çukurova Üniversitesi, Adana, 2018.

Baloğlu, Ayda, "Ve Ateş Bizi Tüketiyor Herkes Kendi Talihinin Mimarıdır", Paros, 2019.

Bulut, Yücel, “Oryantalizm”, Türkiye Diyanet Vakfi İslâm Ansiklopedisi, cilt 33, İstanbul, Türkiye Diyanet Vakfi Yayınları, 2007.

, Oryantalizmin Kısa Tarihi, İstanbul, Küre Yayınları, 2014.

Foucault, Michel, Bilginin Arkeolojisi, çev. V. Urhan, İstanbul, Ayrıntı Yayınlar1, 2014.

Yayınları, 2017.

Hapishanenin Doğuşu, çev. M. A. K1lıçbay, Ankara, İmge

Gülsoy, Murat, Gölgeler ve Hayaller Şehrinde, İstanbul, Can Yayınları, 2014.

, Büyübozumu: Yaratıcı Yazarlık Kurmacanın Bilinen Strları ve İhlal Edilebilir Kurallarl, yay. haz. M. Çevikdoğan, İstanbul, Can Yayınları, 2019. ler-ve-hayaller-sehrinde/, [Erişim Tarihi: 31.03.2020].

İnci, Handan, "Bugünün Gözüyle Ahmet Mithat”, Kitap-lık, 165, 2013.

, "Gölgeler ve Hayaller Şehrinde", Murat Gülsoy: Edebiyatta

30. Yıl Basında Yazılanlar içinde, İstanbul, Can Yayınları, 2014.

Okay, Orhan, Beşir Fuad İlk Türk Pozitivist ve Natüralisti, İstanbul, Hareket Yayınları, 1969.

Oral, Sibel, "Murat Gülsoy'dan Gölgeler ve Hayaller Şehrinde", Cumhuriyet Kitap, 1261, 2014.

Öztunç, Mehmet, "Murat Gülsoy ile Söyleşi”, Türk Dili Dil ve Edebiyat Dergisi, 759, 2015. 
Said, Edward Wadie, Şarkiyatçılık/Batıının Şark Anlayışları, çev. B. Ülner, İstanbul, Metis Yayınları, 2013.

Siralar, Atahan, Murat Gülsoy: Edebiyatta 30. Yıl Basında Yazılanlar, İstanbul, Can Yayınları, 2019. 